\title{
Romanian theology: A theology of DiAlogue
}

\begin{abstract}
Author:
Ioan Chirilă $\breve{1,2}^{1}$

Affiliations:

${ }^{1}$ Faculty of Orthodox Theology, Babes-Bolyai University, Romania

${ }^{2}$ Department of New Testament Studies, Faculty of Theology, University of Pretoria, South Africa
\end{abstract}

\section{Correspondence to:}

Ioan Chirilă

e-mail:

ioanchirila@yahoo.com

\section{Postal address:}

Str. Eremia Grigorescu 114, cod 400304, Cluj-Napoca, jud. Cluj, Romania

\section{Keywords: \\ Romanian theology; \\ Romanian orthodox church; Christian martyria; deification; theosis}

\section{Dates:}

Received: 11 Dec. 2008

Accepted: 11 June 2009

Published: 27 Oct. 2009

How to cite this article: Chirilă, I. 2009, 'Romanian theology: A theology of dialogue', HTS Teologiese Studies/Theological Studies 65(1), Art. \#294, 5 pages. DOI: 10.4102/hts.v65i1.294

\section{This article is available at:} http://www.hts.org.za

\section{Note:}

This article is a reworked version of a paper presented at the Faculty of Theology of the University of Pretoria in 2008. Prof. Dr I. Chirila is a research associate of Prof. Dr J.G. van der Watt, Professor Extraordinarius at the University of Pretoria, South Africa, and a visiting professor at the University of Pretoria.

\section{(c) 2009. The Authors.} Licensee: OpenJournals Publishing. This work is licensed under the Creative Commons Attribution License.

\section{ABSTRACT}

This article offers an overview of the development of Romanian theology through the 20th century, especially after 1989, which constituted a new era for the evolution of Romanian theology. The author believes that the greatest challenge for the Romanian Orthodox Church after 1989 is the one that aims at the reconfiguration of the mission of the Christian martyria within the new forms of religious and social freedom. The author states the necessity for Romanian theology for its own katharsis (purification) as well as the necessity for eliminating the idea that between theology and the other sciences there is a relationship of antinomy. The author firmly states his credo as a theologian, namely the theological theme of deification/theosis, understood either in the way of Saint Paul as 'gods through grace' or in the way of Saint Peter as 'partakers of the divine nature': homo-Deus.

\section{INTRODUCTION}

Through the course of time Christianity has become the foundation of European civilisation. Some speak of Judeo-Christianity; others prefer to speak of a religious diversity able to raise this civilisation to the transcendent truth. I do not want to exclude any of these hypotheses a priori. What is certain is the fact that where many truths exist, there is no truth any more and where only one truth exists, even if apparently there are, from the formal point of view, many ways in which this truth can exist, eventually these ways, by the very convergence of their revealing dynamisms, blend themselves in the uniqueness of the way determined by the transcendent and true uniqueness. From this point of view, we should notice that in the theological field, the way of a priori exclusions, determined by a noxious fundamentalism, should not be adopted, but instead of it, the way of dialogue between ardent desires for the unique truth, expressed in religious forms that call one another toward truth, should be adopted. The dialogical aspect is determined and invoked as a modus vivendi of religious environments by the supreme truth of Christianity, namely that God is a personal spiritual reality, always willing to dialogue with his creation; creation itself by its own logoi invokes dialogue with God through the supreme Logos.

The red years of the suppression of Christianity and of martyrdom broke the Christian martyria (confession of faith); the Romanian environment has been turned into a ghetto. For example, here is a paradoxical reality: In Cluj-Napoca, in the middle of the city, there was an Orthodox theological seminary that was not allowed to express itself in all the years of communism. Nevertheless, its missionary ethos was not destroyed; it burst out from time to time in actions of martyric boldness (missionary actions such as religious concerts under the mask of nationalism, wrongly understood by the atheistic government, and participation in the international reunions of the Ecumenical Council of the churches, from where our theologians, after giving to Caesar what was due to Caesar, brought important theological volumes). These acts of martyric boldness animated at that time the traditional Christian stream into new developments of Christian hope.

Therefore, this sad period was not a totally asphyxiating one for Romanian theology, although it was one constantly aiming at compromising Romanian theology and Christian life. Nevertheless, in this reddish twilight shone the evening star of Romanian theology - Pr Prof. Dr Dumitru Stăniloae - who, after 1989, became the morning star of Romanian theology, who by his theologising opened the way for Romanian theology for its affirmation as a theology of dialogue.

\section{CONTEMPORARY CHALLENGES FOR ROMANIAN THEOLOGY}

The greatest challenge for the Romanian Orthodox Church after 1989 is the aim at the reconfiguration of the mission of the Christian martyria within the new forms of religious and social freedom. Freedom in itself is a challenge; it tends to pull human beings out of their canon, of their natural existence. Romanian theology has been and still is confronted with the secularised concept of freedom. Nevertheless, after 1989, a real explosion of religious manifestations is to be noted in the Romanian social environment. The structure of Romanian religious education has been reorganised as it was before the fall of Romania under the red curtain. We owe this especially to the care of our Orthodox hierarchs and to the kindness, goodwill and understanding of the Ministry of Education and Research. But this represents only a small part of the responsibilities that are incumbent on the church. The economic downturn has generated a large area for manifesting the church diaconate. The diaconal ministry has to be improved even more in order to effectively address all the social problems of Romanian society. A dialogue with the churches of the West is always in development in this sector. Our archbishopric cooperates with the Evangelical Church of Baden-Wurttemberg in Germany, and regarding the diaconate of the laics, it is a vibrant sector due to the foundation of the charity and missionary associations of Orthodox women and Christian youth.

Freedom has brought into our society another challenge too: proselytism. The church is confronted with a missionary assault supported by different Christian denominations and Oriental religious groups. To all of these, a proper answer should be delivered. In this regard, our theological faculties have developed different specialisations in order that our graduates will be able to testify in all Romanian social segments. Besides the pastoral theology specialisation, which trains future priests 
for our churches, hospitals, army and prisons, there are other specialisations that prepare the future teachers of religion, the future social assistants and the future personnel necessary for the conservation and reconstruction of the churches. This fact caused an extensive inter-university cooperation, a real dialogue between religion and culture, because we had to cooperate with different laic faculties. But this also means a completion of the Romanian cultural aspect, secularised forms being now fulfilled with the religious element, the creation on the whole being able to be seen as a church.

Romanian theology is certainly in a stage of recuperating and completing the discourse between religion and culture. The years that have passed by, and the deprivations inflicted by the atheist communist system have isolated Romanian theology and interrupted the dialogue with other contemporary theologies. If we scrutinise the didactic material utilised in our theological schools, we can easily notice that the bibliography we use is from the 1950s. The enclosed system in which Romanian theology developed its activity caused our speech to remain only at a theoretical level, a speech without an immediate impact on the social dimension. Therefore, beside its own katharsis (purification), Romanian theology must recuperate from this methodological discrepancy and the discrepancy of expression. The existent system has introduced the idea of parallelism so deeply as to conclude that between theology and the other sciences there is an antinomic relationship.

On the other hand, the avalanche of information, the bibliographical and communicative possibilities, tends to create problems for Romanian theology as well. There is the risk of syncretic directions, of slipping into an exaggerated historical criticism, into an exaggerated emphasising of biblical philology instead of revelation, placing more confidence in episteme than in revelation. Within the context of this situation, Romanian theology has inaugurated at the Romanian Academy ${ }^{1}$, the main Romanian cultural forum, a real dialogue with science, that is a vivid dialogue with philosophy, history, social sciences, literature and exact sciences, animated by the conviction - according to my point of view - that between scientific knowledge and knowledge through faith there are complementarities, even continuity. Scientific knowledge, as Heidegger said, must have in view a revelatory purpose, and in this way, it is a part of the natural revelation and a stage in rising to knowledge through faith.

To me, the most well-known sector is biblical theology. The main challenge for a Romanian biblicist is the exegetical diversity in contemporary Western theology. In my opinion, the work of the Romanian exegete must follow some clear canonical landmarks: Exegesis is not a demonstratio evangelica but a real method or way through which we become contemporaries with the biblical event. In his works on hermeneutics, Gadamer (2000:20-21, 90$91,160-161)$ says that a text must be understood not only with the mind, rationally, but also with the heart. In this perspective, the Romanian biblicist must observe that the act of interpretation is not one that belongs exclusively to revelation or to the episteme of the immanent sciences but one that continues and stays in unity with the exegesis of the intimates of the apostolic kerygma, with patristic exegesis. The exegetical act is not a new revelation but an articulation of existence in a revealed frame. Therefore, I express some doubts regarding the historical-critical method, the philological method and the demythologising directions. The notion of 'canon' does not refer strictly to the number of books acknowledged by the church as being inspired but especially to the fact that these writings represent a canon for our restoration as person, as anthropos eucharisticos or anthropos leitourgos. When embodied, the text can prepare one for the act

1.A new university discipline, Science and Religion, has been introduced but the main information can be found in the papers proposed by the collection dedicated to the book of scientific epistemology, of inter- and trans-disciplinary study (science-theology-spirituality), Ed. XXI: The Dogmatic Eon, Bucharest, 2002, 2003, 2004. of transcending. In full agreement with these ideas, although I assert the idea of the unity of Scripture and not that of its dichotomy, I have started, in the area of the biblical theology of the Old Testament, to recuperate the exegetical patristic stock. But before this, I considered that it was necessary to recuperate the Judaic thought and the auxiliary disciplines that help us to represent the Old Testament on religious and social levels. Revelation is not contradictory to the logic of existence and creation but enlightens it, causing it to consent to the breathing of the Spirit (hence the term inspiro). I have tried to transmit to my contemporaries my conviction that we must read creation in a theological manner, that every hypostasis of creation has a theological-liturgical implication. Exegetic diversity has been determined by the tendency of accommodating the revelation, the revealed text, to the different interrogations of the present time. I agree that exegetic diversity must give an answer to these interrogations, though not by accommodating itself to them but by assuming them in the framework of revelation, by embodiment, by acquiring them as real speaking of the person from him-/herself

These few explanatory landmarks may give an idea of my theological interests. My favourite theological area of interest has its roots in the speech of Father Dumitru Stăniloae, which embraces the exegesis of Maximos the Confessor and presents to us existence as a 'cosmic liturgy'. I seek the doxological image/icon of creation through which this becomes church and manifests itself in a liturgical symphony.

\section{MATERIALISATIONS OF THE ROMANIAN CHRISTIAN MARTYRIA}

I wish to discuss again the notion of martyria (in the way of confessing the faith) because the existence of theology is not legitimate if it remains at a theoretical level; it must determine the act of theoria, of spiritual contemplation. From the beginnings of Christianity in our present Romanian geographical area, there were two dominant aspects of it: the assertion of dogmatic unity and the apology of the faith and of the liturgical person. I have in mind the theological activities developed by Saint John Cassian (a former theologian of Scythia Minor - Dobrudgea), Gherman, the martyrs from Niculitel, the Scythian monks and the hierarchs who took part in the ecumenical synods.

Another essential characteristic of the Romanian Church is its communitarian expression. It is a well-known fact that the Romanian Church made a substantial contribution to the preservation and sustentation of the holy places, of the monasteries in Athos, of the establishments in Sinai. Romanian theology produced great personalities in the sphere of the confession of faith, such as Metropolitan Peter Moghila/Movila (the confession of faith and the Synod of Jasi - 1642) or Nicolae Milescu Spătaru with his work Enchiridion sive Stella Orientalis Occidentali splendens, in which he explains the Orthodox teaching regarding transubstantiation. Likewise, the Romanian Christian way of living has been founded on an ascetical hesychastic basis; well known in this case are the activities of Paisie Velicikovschi (Pàcurariu 2002:34), of Saint Calinic from Cernica and of the 'ardent Bush' movement, suppressed by the communist regime but still alive, even in the present. We may say that the Romanian Christian way of living is one directed toward spirituality, towards the experience of the Holy Spirit; Romanian theology is a theology of sobornicity (synodality, conciliarity) and of peace.

In Romanian theology, there are some major points that deserve to be mentioned: The systematic section, that of dogmatic thinking, is dominated by the work of Father Stăniloae, whose emphasis is on the concept of person and communion, masterly explained and clarified by the theologians Ioan Ică Senior and

2.Born in Suceava, probably in 1596, son of the Romanian hospodar Simion Movilã, he was Metropolitan of Kiev. With his help, many printing houses and school institutions (teaching was in Latin) were founded (Pàcurariu 2002:317). 
Joan Ică Junior (father and son). The historical section, from the point of view of the history of the Romanian Orthodox Church, is illustriously represented by the academic Mircea Păcurariu. He wrote 20 works of synthesis and books for theological university education and for theological seminaries, more than 100 studies and more than 300 articles. In the same field, I would like to mention the special work of the patrologist I.G. Coman (1984, 1985, 1988). All these remarkable and scientifically accurate activities prove that the Christian Romanian theologian is conscious of the fact that he or she belongs to the great Christian church and therefore he or she acts in the spirit of the undivided church. In the biblical field, I would like to mention Coresi, then the translators of the Bible of Bucharest (1688), Metropolitan Şaguna, Samuil Micu Klein, as well as the contemporary biblicists G. Marcu $(1941 ; 1945 ; 1977)$, N. Neaga (1945; 1985), D. Abrudan (1979; 1994; 1996), V. Mihoc (1983; 2003), S. Tofană (1996), I. Chirilă (1997a; 1997b; 1999a; 1999b; 2000; 2002; 2003), P. Semen $(1993 ; 1996 ; 1997 ; 2000)$ and the Cornitescu brothers. The Romanian biblical school is characterised as a school of an exegetic dialogue between East and West, focusing on the unity and continuity, in the light of inspiration, of the exegetic act, of its spiritual force and power of leading toward theosis (deification/ divinisation or becoming God by grace). Finally, the practical disciplines were and are successfully represented by theologians such as D. Călugăr (1934), E. Branişte (1985; 1993), L. Stan (1939) and L. Streza. In this field, the major point for me is the assertion of the ecclesial aspect of creation and of the fact that its purpose (thelos) is its spiritualisation, creation being itself a church that celebrates the everlasting liturgy.

I gave this account of some of the most representative names of Romanian theology because I took from their work the guidelines for my present theological studies. Nevertheless, their number is greater and their theological work is more substantial than my humble efforts can demonstrate. See for instance Pàcurariu's (2002) The Dictionary of Romanian Theologians, which has 540 pages and contains 790 names.

\section{MY REDISCOVERY OF GOD}

My debut as a writer began with the work Homo-deus. I think that this title easily shows what my credo as a theologian is: It is about the theological theme of deification/divinisation/theosis, understood either in the way of Saint Paul as 'gods through grace' or in the way of Saint Peter as 'partakers of the divine nature'. Therefore, I have started from the very beginning with an interconfessional study, approaching a theme of dogmatic character: the nature of grace - an interconfessional perspective. It is not an approach whose purpose is to prove, starting from such expressions as 'a unique truth' or 'a unique way', the superiority of one confession over the other but an inward personal credo, according to which the truth, as a transcendental reality, manifests itself in all, especially in those circles of spiritual living founded on evangelic and biblical grounds. The entrance into the sphere of grace lights the way for and brings into communion (koinonia) the ones who wander on the paths of this world. The truth and its oneness are closely related to the oneness of the 'way/door': Christ. The conclusion was a simple one, resulting from the simplicity of God: As researchers we must understand that it is not proper to impose on God our way of thinking but we should find ourselves again in the thinking of God. And this very conclusion caused the work Homo-deus.

We, as researchers, can add to this our studies of archaeology and morphology of the sacred space, in which we have shown how the paradigmatic existence of Eden, as a type of the genuine sacred, extends itself into creation through the agency of the holy houses of God but in the end, according to the ecclesiology of Saint Paul (Ephesians 5), fulfils itself and becomes perfect in

3.I have subjectively chosen the authors and titles of the works; there are more than these. They can give us an idea of how Romanian theology developed, the way in which the academic theological discourse reshaped itself after 1989, as well as the way in which it answers to contemporary challenges. creation through humanity-mystical body-ecclesia. Each person must be a presence, a breath of the Holy Ghost, who knows and makes transparent in creation the depths of God. Our rediscovery in God is achieved only when we become conscious of our living in ecclesia and when we ourselves become ecclesia: the source of restoration and sanctification of creation. At this point of my theological studies, an ardent theme appeared: the theme of Logos. After I had studied with much diligence the Christological and soteriological discourse of the Old Testament, I went deeply into the field of Qumran, in vogue at the end of the last century. I have not confined myself strictly to the field of philology, archaeology and the history of the epoch, but I tried to identify the spiritual aspirations of the members of this community, starting from their origin as belonging to the Judaic community. Within the framework of this analysis, I have identified landmarks of Philonian thinking, which led me to old Judaic literature and the Talmudic commentaries, thus finding related aspects between Hellenised Judaism and patristic thinking, such as the obvious relation between Philo and Saint Gregory of Nyssa.

Without being a spirit with Gnostic tendencies - although the modern human being may easily slip into this trap - I gave my attention to Christian gnoseology as well. The result of this study was my paper for my doctoral degree, which deals with the study of 'daat Elohim ve daat Jahwe' in the thinking of Hosea. But here I have still plenty of work to do. In the years to come, together with our enrichment in grace, I will write a treatise on Old Testament gnoseology; for now, I am working at elaborating a theology of the Pentateuch...I would like to support an assertion that was made long ago in Old Testament biblical thinking: The Torah is the backbone of all the categories of Judaic writing and the element that needed perfection, according to the revelation contained in the New Testament, brought by Christ (Mt 5:17).

Another aspect of my theological studies is concerned with the broad theme of anthropology. Here, I have developed a new dimension of the anthropological discourse, the one of teleological anthropology. I think than only to the extent that a person will complete him/herself as a teleological human being will the person be able to detach him/herself from speaking about God from outside and will he or she speak about God from God. I have noticed the symbolic consistency of the discourse of physiological anthropology as well as that of structuralist anthropology, but I would like to underline especially the teleological consistency of the course of humanity through history toward the 'everlasting Pentecost', toward the 'happy eschaton'.

My preoccupations are also directed toward a real dialogue between theology and culture(s); therefore, I can say that what I am doing has more of an interreligious than an interconfessional character. In this field, I have a great interest regarding the theme of faith in the great religions, but I am also trying to identify the cardinal virtues (faith, hope and love) in their different expressions in religious life and in the holy writings of the great religions. All these purposes are achieved in a postgraduate program, the Master's program, initiated by our Faculty, developed in foreign modern languages and entitled 'Theology and Culture'.

My rediscovery in God is actually a liturgical redefining of my existence and an act of re-establishing my sincere dialogue with God in the holy sacraments of confession and Eucharist. We are conscious of the fact that we cannot find ourselves in God by neglecting our neighbours; therefore, this liturgical fact opens us toward serving our neighbours. In this case, my interest is materialised in my effort to identify a real and unsecularised way of adjusting my missionary language to the needs and to the level of perception of my contemporaneity. The present missionary language cannot omit the modern and postmodern vocabulary and agnoia (ignorance), the invasion and the captivity of the human being in the realm of the false image, the burning 
desire for material things and the fact that we are a consumer society. We must develop a new form of apologetic discourse, and I think it is time to rediscover the power of models, of examples of persons who convert others through their presence full of grace.

\section{THE RECEPTION OF THE SECOND VATICAN COUNCIL}

I am not a specialist in this field; therefore, I will only present the conclusions of a great Romanian theologian of dogmatics: Pr Prof. Acad. Dr Dumitru Popescu. He has a very clear and eloquent way of discoursing on Orthodox dogmatic thinking; he is a member in the Theological Commission for Dialogue of the Romanian Orthodox Church with the Roman Catholic Church. His thesis for his doctoral degree is entitled Roman Catholic ecclesiology according to the documents of the Second Vatican Council and its echoes in contemporary theology (Popescu 1972).

The Second Vatican Council was analysed exhaustively and pertinently in Romanian theology. I will mention here only a few of the studies published on this subject in order to make more transparent what I have initially asserted: that Romanian theology is a theology of dialogue. This is apparent from the following titles (space does not allow us to analyse their content): I. Bria - Dogmatic Aspects of the Unity of the Christian Churches (1986); N. Chițescu - The Doctrinary Essence of the Three Great Confessions (1949); N. Chițescu - A Synthesis of Soteriological Dogma: An Interconfessional Approach (1959); N. Nicolaescu - The Roman Catholic Decree on Ecumenism and the Problem of Christian Unity (1967); D. Stăniloae - The Catholic Doctrine of Infallibility at the First and the Second Vatican Council (1965); and V. Sofron - The Decree of the Second Vatican Council Regarding the Laic Apostolate (1967). I have also included some studies from the period prior to the Second Vatican Council because only a comparative perspective can give us an objective perception of the Romanian theologian's attitude toward Western thinking. The reception of the Second Vatican Council was a critical one, a criticism (from the Greek verb krinomai) intended to find the meeting points of the two theological conceptions in order to undertake a theological dialogue.

Professor D. Popescu analyses the documents of the Council and underlines the differences as follows:

... different from the Second Vatican Council, which tends, on the one hand, to isolate the Holy Trinity from the church because it emphasises the divine nature, intransmissible in itself, and, on the other hand, to isolate the church from the Holy Trinity, due to a grace detached from God. Orthodox theology asserts that the Holy Trinity remains open to the church because of the emphasis on the idea of person, which means communication, communion and irradiation of the divine nature, and the church remains open to the Holy Trinity too, because its foundation is the uncreated grace imparted to us by the Holy Ghost...; the theology of the Second Vatican Council has a somewhat deistic character...Orthodox theology is imprinted with a profound theism.

(Popescu 1996:348)

The ecclesiology of the Second Vatican Council, although it speaks of the true fellowship of the bishops and of the people of God, proves to be profoundly juridical and monarchical, while Orthodox ecclesiology has a charismatic, synodal and sobornistic character. The sacraments are vertically orientated between Christ and the church. To the church, Christ appears as sacrament head, and to Christ, the church is sacrament body (Popescu 1996:396). I confine myself only to these ecclesiological aspects; those interested are kindly advised to read the work in its entirety.

In a wider historical perspective, the Second Vatican Council represents the end of a process that started with Saint Augustine. It represents the end of a theology dominated by Platonism or Aristotelianism - and because of that, it ended up in anthropocentrism - and the beginning of a theology that seeks to drink from the doctrinal, liturgical, spiritual and canonical sources of the undivided church (Popescu 1996:450).

The Second Vatican Council, seen as a passage council, created the objective basis for the meeting of the two pillars of the undivided church. It enabled Romanian Orthodoxy to start theological dialogue with the West and turned the Romanian Orthodox Church into a place of pilgrimage for Pope John Paul the second as well as for Bartholomeos I, Archbishop of Constantinople, the new Rome, and ecumenical patriarch.

Our Faculty has initiated a real dialogue with the Roman Catholic academic environment: We have many exchanges with the Catholic Institute in Paris and many remarkable personalities of the Catholic Church have become honorary members of the academic corpus of Cluj-Napoca (e.g. Cardinal Spidlik and Cardinal Kasper). Being a multicultural university, we also have connections with the Protestant world.

\section{THE GIFT OF THE ROMANIAN ORTHODOX CHURCH TO THE DEVELOPMENT OF PAN-EUROPEAN THEOLOGY}

Romanian theology is a theology open to pan-European theology; in Romanian theology, pan-European theology can find hesychia and theoria (contemplation), born from a permanent liturgical dynamis (dynamics). It offers an example of an objective synthesis founded on the dogmatic and canonical expression of the ecumenical synods and represents a medium in which the primary Christian unity, now perceived in diversity, may be tasted through the spirit of sobornicity.

Regarding the dogmatic field, Romanian theology offers a theology of the person that may redefine, in a patristic and apostolic way, the European Christian mission and martyria. From the moral point of view, it offers a theology of love that shows patience, kenosis (humility) and sympathetic waiting for those 'too diverse'. Regarding the historical field, it can offer an objective approach of the treasure of the undivided church, in order to remove all kinds of excess generated by the sin of self-sufficiency. In the sphere of the practical disciplines, it offers a confessing and liturgical theology that leads to the 'cosmic liturgy'; it offers the pattern of a ministry in which the communion and the charismatic unity of all in Christ is accomplished.

Romanian theology offers to Europe a spiritual spring, an example of living in dialogue, and the perfect dialogue for the reunion of all in a single Church is prayer - a way of coming out of oneself in order to serve one's neighbour, that is to serve God the Father through Christ in the Holy Ghost, a way of rediscovering the Trinitarian foundation of the church and of creation, which, in its turn, prays itself with unspeakable groans to be rediscovered in God so as to speak, by way of liturgy, from God.

\section{REFERENCES}

Abrudan, D., 1979, Christianity and Judaism in the perspective of interreligious dialogue, Eibmbor, Bucharest.

Abrudan, D., 1994, Biblical archaeology, Eibmbor, Bucharest.

Abrudan, D., 1996, Biblical Hebrew, Eibmbor, Bucharest.

Braniște, E., [1985] 1993, General liturgics, with some notions of Christian art, Eibmnor, Bucharest.

Bria, I., 1986, Dogmatic aspects of the unity of the Christian churches, Eibmbor, Bucharest.

Călugăr, D., 1934, Christ in school: Seven books of religion, homiletics and catechetics, Publishing House of the Diocese of Roman and Husi, Sibiu.

Chirilă, I., 1997a, Homo-deus, Limes Publishing House, ClujNapoca.

Chirilă, I., 1997b, Messianism and apocalypse in the writings of Qumran, Arhidiecezana, Cluj-Napoca. 
Chirilă, I., 1999a, Qumran and Mariotis, Cluj University Press, Cluj-Napoca.

Chirilă, I., 1999b, The book of the prophet Hosea: Breviarum of the gnoseology of the Old Testament, Limes Publishing House, Cluj-Napoca.

Chirilă, I., 2000, Exegetical fragmentarium, Limes Publishing House, Cluj-Napoca.

Chirilă, I., [2002] 2003, Philonian exegetical fragmentarium, vol. 2, Limes Publishing House, Ciuj-Napoca.

Chiţescu, N.,1949, 'The doctrinary essence of the three great confessions', Theological Studies 9(September-October), 763-780.

Chiţescu, N., 1959, 'A synthesis of soteriological dogma; An interconfessional approach', Orthodoxy 2(April-June), 196217

Coman, I.G., [1984] [1985] 1988, Patrology, Eibmbor, Bucharest.

Gadamer, H.-G., 2000, Truth and method, Teora, Bucharest.

Marcu, G., 1941, Paulinian anthropology, Printing House of the Archdiocese of Sibiu, Sibiu.

Marcu, G., 1945, The process of our Saviour, Printing House of the Archdiocese of Sibiu, Sibiu.

Marcu, G., Nicolaescu, N., Sofron, V. \& Munteanu, L.G., 1977, The study of the New Testament, Eibmbor, Bucharest.

Mihoc, V., 1983, The epistle of Saint Paul to the Galatians, Eibmbor, Bucharest.

Mihoc, V., 2003, A commentary to the fourth Gospel, Theophany Publishing House, Sibiu.

Neaga, N., 1945, Christ in the Old Testament, Printing House of the Archdiocese of Sibiu, Sibiu.

Nicolaescu, N., 1967, 'The Roman Catholic decree on ecumenism and the problem of Christian unity', Orthodoxy Review 2(April-June), 293-301.

Pàcurariu, M. (ed.), 2002, The dictionary of Romanian theologians, Encyclopaedic Universe Editions, Bucharest.
Popescu, D., 1972, 'In the review', Orthodoxy XXIV(3), n.p. Popescu, D., 1993, Theology and culture, Eibmbor, Bucharest.

Popescu, D., 1996, Orthodoxy and present times, Diogene, Bucharest.

Popescu, D., 1998, Christ, church, society, Eibmbor, Bucharest.

Semen, P., 1993, Saint and sanctity in the Old Testament, Publishing House of the Diocese of Moldavia and Bucovina, Iasi.

Semen, P., 1996, Elements of the grammar of the biblical Hebraic language, Publishing House of the A.I. Cuza University in Iasi, Iasi.

Semen, P., 2000, Waiting for redemption, Publishing House of the Diocese of Moldavia and Bucovina, Iasi.

Şofron, V., 1967, 'The decree of the Second Vatican Council regarding the laic apostolate', Orthodoxy 4(OctoberDecember), 541-549.

Stan, L., 1939, The laics in the church, Printing House of the Archdiocese of Sibiu, Sibiu.

Stăniloae, D, 1942,. Philokalia, transl. Fr. D. Stăniloae, 12 vols. Printing House of the Archdiocese of Sibiu, Sibiu Stăniloae, D., 1965, 'The catholic doctrine of infallibility at the first and the Second Vatican Council', Orthodoxy Review 4(OctoberDecember), 459-492.

Stăniloae, D., 1981, Orthodox spirituality, Eibmbor, Bucharest.

Stăniloae, D., 1986, Spirituality and communion in Orthodox liturgy, Publishing House of the Metropolitan Bishopric of Oltenia, Craiova.

Stăniloae, D., 2002, Orthodox dogmatic theology, vol. 1, Eibmbor, Bucharest.

Tofană, S., 1996, Jesus Christ, an archyereus for ever, according to the epistle to the Hebrews, Cluj University Press, Cluj-Napoca.

Tofană, S., [2002] 2003, Introduction into the study of the New Testament, 3 vol., Cluj University Press, Cluj-Napoca. 